\title{
Telemetriás és online nontelemetriás adatok elemzése szívelégtelen betegek fizikai aktivitásának jellemzésére
}

\author{
Melczer Csaba ${ }^{1}$ - Melczer László dr. ${ }^{2}$ - Goják Ilona dr. ${ }^{2}$ \\ Kónyi Attila dr. ${ }^{2}$ - Szabados Sándor dr. ${ }^{2}$ - Raposa László Bence ${ }^{3}$ \\ Oláh András dr. ${ }^{4}$ - Ács Pongrác dr. ${ }^{1}$ \\ Pécsi Tudományegyetem, 'Egészségtudományi Kar, Fizioterápiás és Sporttudományi Intézet, \\ ${ }^{2}$ Klinikai Központ, Szívgyógyászati Klinika, \\ ${ }^{3}$ Egészségtudományi Kar, Táplálkozástudományi és Dietetikai Intézet, \\ ${ }^{4}$ Egészségtudományi Kar, Ápolástudományi, Alapozó Egészségtudományi és Védőnői Intézet, Pécs
}

\begin{abstract}
Bevezetés: Több kutatás kimutatta, hogy a szívelégtelenség prevalenciája a nyugati országokban 0,4-2\% közötti értékre tehetô.

Célkitüzés: Tanulmányunk célja annak meghatározása volt, hogy a szívelégtelenséggel élő betegeknél a telemetriás úton kapott fizikai aktivitás százalékos érték felhasználásával megbecsülhető-e a hatperces sétateszt során megtett távolság.

Módszer: A kutatásba 17, szívelégtelenségben szenvedő beteget vontunk be ( $\mathrm{n}=17$; életkor 57,35 év \pm 9,54; testtömeg 98,71 kg \pm 9,89; átlag-BMI 36,69 $\pm 3,67)$. A fizikai aktivitást jellemző két adatsor felhasználásával lineáris regressziót végeztünk, amelynek során egy matematikai egyenletet kaptunk, így a fizikai aktivitás százalékérték segítségével becsülhető a hatperces sétateszt során megtett távolság.

Eredmények: A kapott adataink további elemzése során arra a következtetésre jutottunk, hogy e betegeknél a CRTkészülékbőll származó adatok közül a PA\% segítségével becsülhetővé válik a hatperces séta alatt megtett távolság, amely e betegek terhelhetőségének egyik jellemző információja lehet.

Következtetések: Módszerünk felhasználásával a betegek állapotváltozása az implantált elektronikus eszközzel telemetriásan folyamatosan követhető.
\end{abstract}

Orv Hetil. 2017; 158(35): 1390-1395.

Kulcsszavak: szívelégtelenség, CRT, fizikai aktivitás, PA\%, 6MWT

\section{Analysis of telemetry, on-line and non-telemetry data for characterization of the physical activity of patients with heart failure}

Introduction: Several studies have demonstrated that the prevalence of heart disease can be accounted for between 0.4 and $2 \%$ in developed countries.

Aim: The present study aimed to use the PA\% of the telemetry data to estimate the 6-minute walk test result. Method: A total of seventeen patients with heart disease; 3 females and 14 males; age: 57.35 yrs \pm 9.54 ; body mass $98.71 \pm 9.89 \mathrm{~kg}$; average BMI $36.69 \pm 3.67$ were recruited into the study. Using the two sets of values describing physical performance, linear regression was calculated providing a mathematical equation, thus, the Physical Activity $\%$ value is used to estimate the distance traveled over a 6-minute walk test.

Results: On further data analysis, we have come to the conclusion that the distance walked during the six-minute-long test may be measured by PA\% from the data of CRT device.

Conclusions: With our method, based on the values received from the physical activity sensor implanted into the resynchronisation devices, changes in patients' health status could be monitored telemetrically with the assistance from the implanted electronic device.

Keywords: heart failure, physical activity, PA\%, 6MWT

Melczer Cs, Melczer L, Goják I, Kónyi A, Szabados S, Raposa LB, Oláh A, Ács P. [Analysis of telemetry, on-line and non-telemetry data for characterization of the physical activity of patients with heart failure]. Orv Hetil. 2017; 158(35): 1390-1395.

(Beérkezett: 2017. június 12.; elfogadva: 2017. július 10.) 


\section{Rövidítések}

$6 \mathrm{MWT}=(6$ minutes walk test $)$ hatperces sétateszt; BMI = (body mass index) testtömegindex; BTSZB = bal-Tawara-szárblokk; CRT $=$ (cardiac resynchronization therapy) kardiális reszinkronizációs terápia; CRTD - reszinkronizációs defibrillátor, CRTP-kezelés = reszinkronizáció pacemakerrel; ESC $=($ European Society of Cardiology $)$ Európai Kardiológus Társaság; HM-készülék = (home monitoring) távoli ellenőrzés lehetőségét biztosító készülék; MET-érték = metabolikus ekvivalens (nyugalomban mért oxigénszükséglet); MPA = (moderate physical activity) közepes erősségü fizikai aktivitás; MVPA $=($ moderate-vigorous physical activity) közepes és erôs fizikai aktivitás; NYHA $=($ New York Heart Association $)$ New York-i Szívbetegséggel Foglalkozó Társaság; PTE KK = Pécsi Tudományegyetem, Klinikai Központ

Egészséges populációra vonatkoztatva jól ismert a rendszeres fizikai aktivitás egészségre gyakorolt jótékony hatása. Több kutatás leírta, hogy a szívbetegek számára is nélkülözhetetlen, valamint az ülő életmódot folytató szívbetegeknél szekunder prevenciós hatását is kimutatták [1-5]. Több kutatás szerint a szívelégtelenség prevalenciája a nyugati országokban $0,4-2 \%$ közötti értékre tehető. Ez az érték 40 éves korra $1 \%$ körül alakul, míg 75 éves kor felett $10 \%$ [6]. Incidenciája 2-4/1000 fó, a diagnózisát követő négyéves mortalitás $50 \%$ körül alakul [7]. Tomcsányi 2012-ben végzett kutatása szerint [8] Magyarországon e betegség prevalenciája 1,6\%, ami 160 ezer beteget jelent. Incidenciája 30-40 000 között változik évente. Jellemzően a 60-80 éves korosztályba tartoznak az érintettek. Napjainkban a nemzetközi irányelvek a krónikus szívelégtelenség kezelésének alapvető céljaként a tünetek megszüntetését javasolják, amely a kórházi kezelés megelőzését és a túlélés javítását jelentheti $[6,9]$. Jelenleg a szisztolés szívelégtelenségben szenvedő betegek esetében a cardiac resynchronization therapy (CRT) az egyik legeredményesebb eszközös beavatkozás, amelyet az Európai Kardiológus Társaság (ESC) is leírt az ajánlásában (EHRA/HRS guideline 2012) [10, 11]. A CRTP-kezelés (reszinkronizáció pacemakerrel) 2371 beteg metaanalízise alapján szignifikánsan, 29\%-kal csökkenti az összmortalitást [12]. Az aritmia okozta elhalálozás magas rizikója esetén azonban CRTD beültetése ajánlott [11]. Ricci és mtsai felhívták a figyelmet arra, hogy a CRT-készülékek 90\% feletti hatékonysággal szûrik ki az életet veszélyeztető aritmiákat, de relatíve alacsony hatékonyságot mutatnak $(58,8 \%)$ a betegek állapotromlásának előrejelzése esetében [13]. Beültetési kritériumok a csökkent bal kamrai ejekciós frakció (EF: $\leq 35 \%$ ), bal-Tawara-szár-blokk (BTSZB) QRS ( $\geq 130$ $\mathrm{ms}$ ), illetve a betegek klinikai állapotát jelző NYHA-stádium (NYHA II-IV). A svéd szívelégtelenség-regiszter [14] rámutatott arra, hogy a szisztolés szívelégtelen betegek 69\%-a keskeny QRS-sel $(<120 \mathrm{~ms})$ rendelkezik, így nem alkalmas CRT-kezelésre. A szívelégtelenség egyik jellemzője a csökkent fizikai terhelhetőség, amelylyel együtt csökken a napi fizikai aktivitás is. Ez általános inaktivást eredményez és tovább romlik az egyén terhelhetősége [15]. Ezeken túlmenően a szívelégtelenség során a csökkent fizikai aktivitás miatt olyan kórképek is megjelenhetnek, mint a depresszió, ami az életminőséget rontja [16]. Myers és mtsai egy 2015-ös tanulmányukban [17] leírják, hogy a stabil állapotú szívbetegek fizikai edzése javítja az állapotukat, nem okoz további károsodást, és számos előnyt hoz: csökkenti a morbiditást, a mortalitást és a kórházi ápolás szükségességét. A fentiekből is kitûnik, hogy a betegek életminősége az utóbbi idôben egyre fontosabbá vált, e fogalom egyik pillére a fizikai aktivitás, amelynek mértéke jól jelzi a betegek állapotát. A technológia fejlődése lehetôvé tette a fizikai aktivitás monitorozását akár a beültetett CRT-készüléken keresztül is. A CRT-készülékek beépített (belső) kapacitív akcelerométere képes mérni a mozgások kinematikai jellemzőit, és azokról értékelést is ad [18]. A belső akcelerométer egy piezoelektromos kristályt tartalmaz, amely érzékeli a test mozgásának intenzitását és frekvenciáját, majd e jeleket elektromos impulzusokká alakítja és a többi lekérdezett adattal együtt telemetriás úton továbbítja egy mobil telefonegységen keresztül a gyártó központi adatfeldolgozó rendszerébe. A telemetriás úton továbbított, feldolgozott adatok értékes információkat jelentenek a kezelőorvos számára, így a beteg állapota távolról monitorozható. Tanulmányok igazolták a Biotronik home monitoring (HM) rendszerének hatékonyságát, mortalitást csökkentő szerepét $[19,20]$. Ezen a módon a napi aktivitás százalékban megadott értékét elemezheti a kezelőorvos, azonban érdemes megvizsgálni a betegek aktivitásának intenzitását is, amely így pontosabb képet ad a terhelhetőségükról. Erre ad lehetőséget az Actigraph mozgáselemző szenzora (Actigraph GT3X+). Ez a mozgáselemző szenzor képes a mozgásintenzitástól függően osztályozni az aktivitásokat és ezzel az elvégzett napi mozgásmennyiséget meghatározni. Erre vonatkozóan Howell 2008-ban megjelent tanulmányában leírta, hogy a vizsgálati mintáját alkotó szívelégtelen betegek fizikai aktivitása jellemzően az ülő életmód és az alacsony aktivitási szinteknek volt megfelelő [21]. A szívelégtelen betegek alacsony aktivitását más kutatások is vizsgálták. Melczer és mtsai 2015-ben zajlott kutatásukban a szívelégtelen betegek energiafelhasználását számszerúsítve azt találták, hogy a mintájukban a METérték $1,12 \pm 0,04$ volt [22]. A szívelégtelen betegek esetében a napi fizikai aktivitás mértéke a mortalitás egy független változója [23]. Több tanulmány jelzi, hogy az egészségvédő hatást kiváltja bármilyen típusú, heti rendszerességgel alkalmanként több mint 10 percig végzett, legalább közepes intenzitású fizikai aktivitás (moderate physical activity - MPA) [24, 25]. Az egészségre bizonyítottan pozitív hatást gyakorló fizikai aktivitás meghatározásának fontos eleme az egység-idő (Bout/egybefüggően, legalább 10 perc közepes fizikai aktivitás), amit a kutatások eredményeikben megjelenítenek. Tanulmányunkban az adott minta esetében a fizikai aktivitást egy külső mozgásérzékelő szenzorból kapott adatok segítsé- 
gével kívántuk megvizsgálni, valamint a beültetett készülékekből szimultán nyert telemetriás adatok közül a PA\% alapján megbecsülni a hatperces sétateszt során elért fizikai teljesítmény mértékét, továbbá ezen adatok birtokában bizonyítani a PA\% gyakorlati alkalmazhatóságát a fizikai aktivitás megítélésére ebben a betegcsoportban.

\section{Betegek és módszer}

A kutatásba a Pécsi Tudományegyetem, Szívgyógyászati Klinika azon betegeit vontuk be, akiknél megfelelő készülék került beültetésre.

Beválasztási kritériumok:

- ESC által javasolt kritériumrendszernek megfelelő betegek:

- szisztolés szívelégtelenség, $\mathrm{EF}<35 \%$,

- bal-Tawara-szár-blokk (QRS>130 ms),

- NYHA II-III. klinikai stádium.

- Implantált Biotonik CRTP- vagy CRTD-készülék home monitoring (HM) rendszerrel.

- A HM-rendszer folyamatos használata.

- Életkor>8 év, tartós sinusrhythmus.

- Alárt beleegyező nyilatkozat. Kizárási kritériumok:

- NYHA IV. klinikai stádium.

- A HM-rendszer használatának elutasítása.

- Járáskorlátozottság, amely kizárja a 6MWT teljesítését.

- Tartósan pitvarfibrilláló CRT-betegek.

- Együttmúködés hiánya.

Előzetesen 21 beteg került kiválasztásra a fenti kritériumok figyelembevételével. Egy fő járáskorlátozottság miatt kizárásra került három fó nem kívánt részt venni a kutatásban. Így $\mathrm{n}=17$; életkor 57,35 év $\pm 9,54$; testtömeg 98,71 kg $\pm 9,89$; átlag-BMI 36,69 $\pm 3,67$; négy fó $\mathrm{BMI} \leq 30 ; 13$ fó $\mathrm{BMI} \geq 30$ (1. táblázat).

A betegek CRT-készülékéből kinyert és az Actigraph adatait hétnapos intervallumban vizsgáltuk 2015. április 10. és április 17. között. Az Actigraph GT3X+ készülék a három térirányban történő mozgások erősségét méri, valamint ezek időtartamát rögzíti. Egy ütés alatt azt a jelet értjük, amelynek a magnitúdója elegendő arra, hogy a jelet az akcelerométer analógból digitálissá alakítsa. Ez az eszköz lehetôvé teszi, hogy a napi aktivitást pontosan felmérjük, és ezáltal kategóriákba soroljuk. Egy meghatározott képlet alapján Freedson és mtsai oxigénfogyasztási mennyiségeket rendeltek az ütés/perc adathoz, amelynek segítségével az aktivitáskategóriák MET-értékei meghatározhatók.

A fentiek alapján az aktivitási szintek a következők:

- ülő (sedentary) a 0-99 ütés/perc alatti;

- könnyű (light) fizikai aktivitás: 100-1951 ütés/perc, $\leq 3$ MET;

- közepes (moderate) az 1952-5724 ütés/perc közötti, $\geq 3$ MET és <6 MET;
1. táblázat |A minta jellemzői

\begin{tabular}{ll}
\hline Férfi/nő (fó) & $14 / 3$ \\
Átlagéletkor (év) & $57,35 \pm 9,54$ \\
Testtömeg (kg) & $98,71 \pm 9,89$ \\
Átlag-BMI & $36,69 \pm 3,67$ \\
NICM (fó) & 13 \\
ICM (fó) & 8 \\
Valvular HD (foó) & 2 \\
NYHA II. (fó) & 8 \\
NYHA III. (fó) & 9 \\
Magas vérnyomás (fó) & 10 \\
Cukorbetegség (fó) & 5 \\
Infarktus (fó) & 4 \\
Szívbillentyücsere (fó) & 2 \\
VT/VF (fó) & 7 \\
AF (fó) & 2 \\
Asztma (fó) & 2 \\
ACBG (fó) & 2 \\
PTCA (fó) & 2 \\
\hline
\end{tabular}

ACBG = koszorúér-áthidalás; $\mathrm{AF}=$ pitvarfibrilláció; $\mathrm{ICM}=$ ischaemiás cardiomyopathia; NICM = nem ischaemiás cardiomyopathia; PTCA = koszorúér-tágítás stentbeültetéssel; valvular HD = szívbillentyü-betegség; VT/VF = kamrai tachycardia/kamrafibrilláció

Forrás: Saját adatok

- intenzív (vigorous) az 5725-9498 ütés/perc közötti, $\geq 6$ és <9 MET;

- nagyon intenzív (very vigorous) aktivitásnak a >9498 ütés/perc érték számított, $\geq 9$ MET [26].

Alanyaink a tartósan vízben tartózkodást (tisztálkodás, úszás) kivéve állandóan viselték a szenzort. Az Actigraph GT3X+ adatainak elemzése során öt epoch (mintavételi sűrüség, öt másodpercenkénti egységben) időket állítottunk be.

A vizsgálat hatperces sétateszttel (6MWT) vette kezdetét. A teszt megkezdése előtt a betegek információt kaptak a feladat végrehajtásáról. Ennek értelmében a teszt során sétáljanak olyan sebességgel, amilyen gyorsan tudnak, de lassítsanak vagy akár álljanak meg, ha az szükséges. A hatperces sétatesztet egy 20 m hosszú, sík területen végezték. A 20 m-es hossz mindkét végén székek álltak a betegek rendelkezésére, annak érdekében, ha a teszt során a betegek elfáradnának, megpihenhessenek. A vizsgálatba bevont személyek mindegyikének Biotronik készüléket ültettek be, amelyek beépített antennával rendelkezve biztosítják az adatátvitel lehetőségét a mobiltelefon-egységre. Négy fö Iforia $5 \mathrm{HF}-\mathrm{T}$, négy fö Lumax 540 HF-T és hét fö Lumax 640 HF-T, két fó Entovis HF-T készülékkel él. Az előbbiek szívingerlő defibrillátorok, az utóbbi (Entovis) szívingerlő készülék. 
Az adatfeldolgozás SPSS 23 statisztikai csomag és Excel felhasználásával történt. A statisztikai elemzés során leíró statisztikát, korrelációelemzést, logisztikus regreszszió számítást végeztünk.

\section{Eredmények}

A statisztikai elemzés után kapott adatokból kitúnik, hogy ebben a vizsgálati csoportban tendenciaként figyelhető meg, hogy minél magasabb az egyén BMI-értéke, annál több időt töltött el ülve $(\mathrm{p}=0,029 ; \mathrm{R}=0,507)$. Ezt tovább erősítette az a negatív korreláció, amelynek értelmében az alacsonyabb testtömegindexű személyek több időt töltöttek közepes aktivitással $(\mathrm{p}=0,02 \mathrm{l} ; \mathrm{R}=$ $-0,555)$. Az is láthatóvá vált, hogy azok a személyek, akik több időt töltöttek a közepes és/vagy intenzív kategóriában, nagyobb távot voltak képesek megtenni a hatperces sétateszt során $(\mathrm{p}=0,031 ; \mathrm{R}=0,524)$.

Az 1. ábrán az ülő életmód, a könnyư és közepes aktivitás kategóriákban eltöltött idő százalékos alakulását látjuk. Ebből nyilvánvaló, hogy betegeink a vizsgált időszak 86,79\%-át ülő és csak 10,75\%-át, illetve 2,46\%-át töltöttek könnyű, illetve közepes kategóriájú mozgással. Ezen adatok alapján a mintában részt vevők jellemzően ülő életmódot folytatnak, és amennyiben végeznek is fizikai aktivitást, az alacsony mértékü. Kevesebb, mint ami szükséges volna e betegek számára az életminőségük megtartása szempontjából.

A 2. ábra mutatja, hogy a páciensek az inaktivitást jelentő ülő kategórián kívül leginkább a könnyű fizikai aktivitás kategóriában végeznek tevékenységeket, amely 3 MET alatti tevékenységnek felel meg.

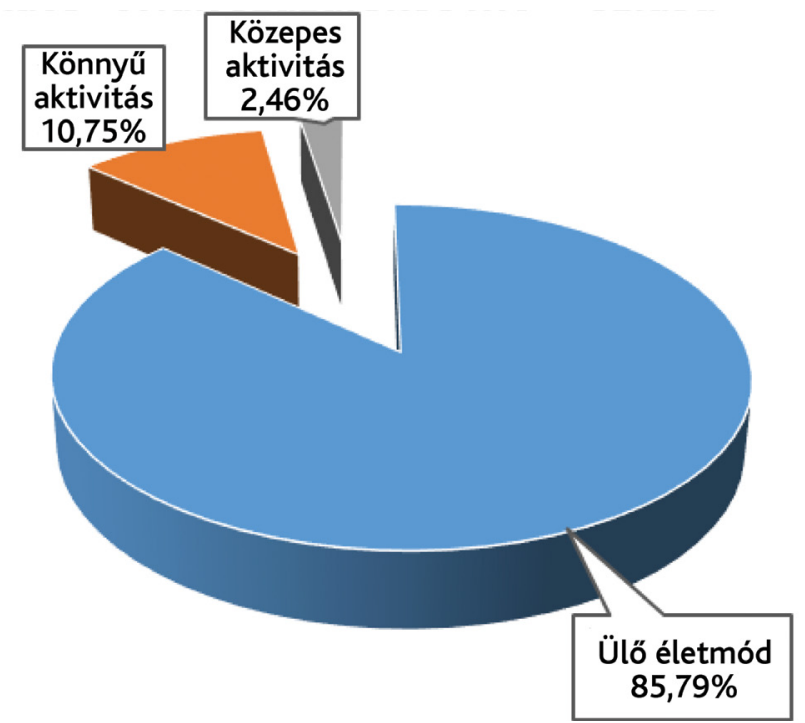

1. ábra $\begin{aligned} & \text { A különböző aktivitáskategóriákban eltöltött idő százalékos } \\ & \text { megoszlása }\end{aligned}$
Forrás: saját adatok

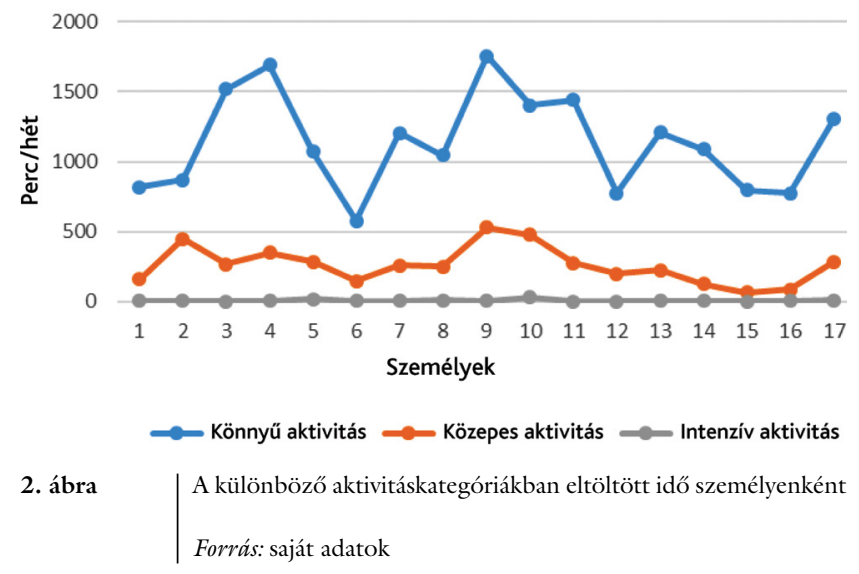

Végül a hatperces sétateszt során teljesített, méterben mért távolságokat összevetettük a CRT-készülékekből származó napi fizikai aktivitást jellemző adatsorral (PA\%). Itt egy értékes összefüggést találtunk. A statisztikai elemzés során a két adatsort lineáris regresszió segítségével vizsgáltuk, és e számítás azt mutatta, hogy a PA\% adatából egy regressziós egyenlet segítségével megbecsülhető a páciens hat perc alatt méterben megtett távolsága. A lineáris regresszió számítás során a következő paramétereket kaptuk: $\mathrm{F}=4,409 ; \mathrm{p}=0,05 ; \mathrm{b}_{0}$ paraméter 335,321 $(\mathrm{p}=0,00), \mathrm{a}_{1}$ paraméter $4,925(\mathrm{p}=0,05)$. Tehát $\mathrm{a}$ hatperces sétateszt becsült távolságát a következő egyenlettel kapjuk meg: $\mathrm{y}=335,321+4,925^{*} \mathrm{x}$

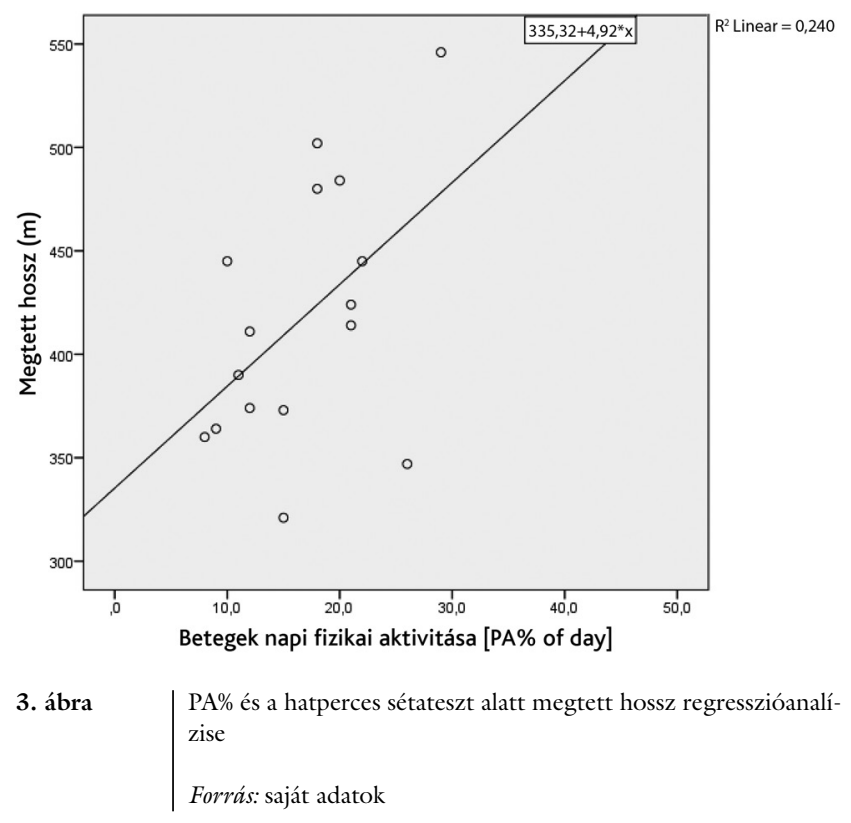

\section{Következtetések}

A kutatásunkban a szívelégtelen betegek fizikai aktivitását vizsgáltuk, amelynek során a betegek által egy héten át viselt külső aktivitásmonitor (Actigraph GT3X+) adatait vetettük össze a beültetett CRT-készülékből szárma- 
zó adatokkal. Elmondható, hogy a betegek az irodalmi adatoknak megfelelően $[15,21,22]$ általánosan alacsony aktivitási szinteket mutattak. Az is kiderült, hogy azok, akik magasabb BMI-vel rendelkeznek, alacsonyabb mozgási aktivitást mutattak, mint az alacsonyabb testtömegindexszel rendelkezők. Továbbá azok, akik a közepes aktivitás kategóriában több időt töltöttek, hosszabb távot tudtak megtenni a hatperces sétateszt során. Ezen adatok alapján érdemes volna ennél a betegcsoportnál az életminőség javítása érdekében egy kontrollálható edzéstervet készíteni és a betegeket ennek eredményeivel inspirálni a számukra optimális fizikai teljesítmény elérésére.

Ricci és mtsai felhívták a figyelmet arra, hogy a CRTkészülékek 90\% feletti hatékonysággal szürik ki az életet veszélyeztető aritmiákat, de relatíve alacsony hatékonyságot mutatnak $(58,8 \%)$ a betegek állapotromlásának előrejelzése esetében [13]. A kapott adataink további elemzése során arra a következtetésre jutottunk, hogy e betegek esetében a CRT-készülékből származó adatok közül a PA\% felhasználásával, az általunk megadott képlet alkalmazásával, becsülhetővé vált a hatperces séta alatt megtett távolság, amely e betegek terhelhetőségének egyik jellemző klinikai adata. A PA\% telemetriás úton történő folyamatos monitorozásával a teljesítménycsökkenés korán észlelhető és gyors terápiás beavatkozást tesz lehetővé. Mindez kiegészíthető a szívelégtelenség további telemetriás paramétereinek értékelésével. Így a szisztolés szívelégtelen betegek azon csoportjánál, akik távoli ellenőrzést biztosító CRT-készülékkel élnek, lehetőség nyílik a fizikai teljesítmény ellenőrzésére ambuláns megjelenés nélkül. A kezelőorvos így „individuális, interaktív edzéstervet" készíthet betegeinek és ellenőrizheti annak megvalósulását. A távoli ellenőrzés lehetőségével rendelkező CRT-készülékek kiterjesztett alkalmazásának feltétele a financiális feltételek biztosítása. Emellett szükséges a távoli ellenőrzés technikai, személyi hátterének, finanszírozásának kialakítása. E tevékenység megszervezése távlatilag a betegek mortalitáscsökkenéséhez vezetve [20] a klinikai és ambuláns ellátás költségcsökkentő tényezője lehet, jelentős szemléletváltozást hozva a szívelégtelen betegek kezelésében. A svéd szívelégtelenségregiszter alapján a szívelégtelenségben (szisztolés/diasztolés) szenvedók 69\%-a keskeny QRS-sel él [14]. A széles QRS-sel élők közül a BTSZB-kel élők számára van hatásos eszközös lehetőség a szívizom mechanikus öszszerendezésével a szívteljesítményük javítására. A keskeny QRS-sel élők számára egyelőre az optimális gyógyszeres kezelés, testsúlycsökkentés és a testedzés áll rendelkezésre a rehabilitáció során [11].

A szívelégtelen betegek számának emelkedése felveti az egyénre szabott, megfelelő detektálási technikával kiegészített, mozgásintenzitást is figyelembe vevő, ellenőrizhető így a szívbetegek edzettségi állapotát, életkilátásait javító rehabilitációs rendszer bevezetését. Különös tekintettel az okostelefonokra épített, sokat ígérő távoli ellenőrzési módszerek alkalmazási lehetőségeire.
A fenti vizsgálat eredményeinek alátámasztására elindított kutatás folyamatban van nagyobb számú - azonos betegcsoportú és azonos beválasztási kritériumokkal rendelkező - betegcsoporttal.

Anyagi támogatás: A közlemény megírása, illetve a kapcsolódó kutatómunka anyagi támogatásban nem részesült.

Szerzői munkamegosztás: M. Cs.: A kutatás lefolytatása, a szöveg megírása. M. L.: Hipotézisek felállítása, a szöveg javítása. G. I.: Betegek ultrahangvizsgálata és kiválasztása. K. A.: A betegek operálása, kiválasztása. R. L. B., Á. P.: Statisztikai elemzés, mérések lefolytatása. O. A.: Eredmények interpretációja. A cikk végleges változatát valamennyi szerző elolvasta és jóváhagyta.

Érdekeltségek: A szerzőknek nincsenek érdekeltségeik.

\section{Irodalom}

[1] Dua JS, Cooper AR, Fox KR, et al. Exercise training in adults with congenital heart disease: feasibility and benefits. Int J Cardiol. 2010; 138: 196-205.

[2] Evenson KR, Butler EN, Rosamond WD. Prevalence of physical activity and sedentary behavior among adults with cardiovascular disease in the United States. J Cardiopulm Rehabil Prev. 2014; 34: 406-419

[3] Flynn KE, Piña IL, Whellan DJ, et al. Effects of exercise training on health status in patients with chronic heart failure: HFACTION randomized controlled trial. JAMA 2009; 301: 14511459.

[4] O'Connor CM, Whellan DJ, Lee KL, et al. Efficacy and safety of exercise training in patients with chronic heart failure: HFACTION randomized controlled trial. JAMA 2009; 301: 14391450 .

[5] Jehn M, Schmidt-Trucksäss A, Schuster T, et al. Daily walking performance as an independent predictor of advanced heart failure: Prediction of exercise capacity in chronic heart failure. Am Heart J. 2009; 157: 292-298.

[6] Dickstein K, Cohen-Solal A, Filippatos G, et al. ESC Guidelines for the diagnosis and treatment of acute and chronic heart failure 2008: The Task Force for the Diagnosis and Treatment of Acute and Chronic Heart Failure 2008 of the European Society of Cardiology. Developed in collaboration with the Heart Failure Association of the ESC (HFA) and endorsed by the European Society of Intensive Care Medicine (ESICM). Eur J Heart Fail. 2008; 10: 933-989.

[7] Roger VL. The heart failure epidemic. Int J Environ Res Public Health 2010; 7: 1807-1830.

[8] Tomcsányi J, Tóth E. Epidemiology and therapy of heart failure in the early XXI century. [Szívelégtelenség epidemiológiája és terápiája Magyarországon a XXI. század elején.] Cardiologia Hungarica 2012; 42: 42-49. [Hungarian]

[9] McMurray JJ, Adamopoulos S, Anker SD, et al. ESC Guidelines for the diagnosis and treatment of acute and chronic heart failure 2012: The Task Force for the Diagnosis and Treatment of Acute and Chronic Heart Failure 2012 of the European Society of Cardiology. Developed in collaboration with the Heart Failure Association (HFA) of the ESC. Eur Heart J. 2012; 33: 1787-1847.

[10] Ponikowski P, Voors AA, Anker SD, et al. 2016 ESC Guidelines for the diagnosis and treatment of acute and chronic heart failure: The Task Force for the diagnosis and treatment of acute and chronic heart failure of the European Society of Cardiology 
(ESC). Developed with the special contribution of the Heart Failure Association (HFA) of the ESC. Eur Heart J. 2016; 37: 2129-2200.

[11] Brignole M, Auricchio A, Baron-Esquivias G, et al. 2013 ESC Guidelines on cardiac pacing and cardiac resynchronization therapy. The Task Force on cardiac pacing and resynchronization therapy of the European Society of Cadiology (ESC). Developed in collaboration with the European Heart Rhythm Association (EHRA). Eur Heart J. 2013; 29: 2281-2329.

[12] Merkely B. Resynchronization therapy of heart failure. [A szívelégtelenség reszinkronizációs kezelése.] Cardiologia Hungarica 2008; 38: 40-45. [Hungarian]

[13] Ricci RP, Morichelli L, D'Onofrio A, et al. Effectiveness of remote monitoring of CIEDs in detection and treatment of clinical and device-related cardiovascular events in daily practice: the HomeGuide Registry. Europace 2013; 15: 970-977.

[14] Lund LH, Jurga J, Edner M, et al. Prevalance, correlates, and prognostic significance of QRS prolongation in heart failure with reduced and preserved ejection fraction. Eur Heart J. 2013; 34 529-539.

[15] Witham MD, Argo IS, Johnston DW, et al. Predictors of exercise capacity and everyday activity in older heart failure patients. Eur J Heart Fail. 2006; 8: 203-207.

[16] Alosco ML, Spitznagel MB, Miller L, et al. Depression is associated with reduced physical activity in persons with heart failure. Health Psychol. 2012; 31: 754-762.

[17] Myers J, Brawner CA, Haykowsky MJ, et al. Prognosis: does exercise training reduce adverse events in heart failure? Heart Fail Clin. 2015; 11: 59-72.

[18] Lau CP, Siu CW, Tse HF. Implanted sensors for rate adaptation and hemodynamic monitoring. In: Ellenbogen KA, Kay GN, Lau CP, et al. Clinical cardiac pacing, defibrillation and resynchronization therapy. Fourth edition. Elsevier, 2011; Section I, pp. 144-174
[19] Varma N, Epstein A, Irimpen A, et al. Efficacy and safety of au tomatic remote monitoring for implantable cardioverter-defibrillator follow-up: the Lumos-T Safely Reduces Routine Office Device Follow-up (TRUST) trial. Circulation 2010; 122: 325332.

[20] Hindricks G, Taborsky M, Glikson M, et al. Implant-based multiparameter telemonitoring of patients with heart failure (INTIME): a randomised controlled trial. Lancet $2014 ; 384$ : 583590.

[21] Howell J, Delisle S, Jones M, et al. Actigraphy in heart failure subjects with a reduced and normal ejection fraction. J Cardiac Fail. 2008; 14(Suppl): S110.

[22] Melczer Cs, Melczer L, Goják I, et al. Telemetry data based on comparative study of physical activity in patients with resynchronization device. [Reszinkronizációs készülékkel élő betegek fizikai aktivitásának összehasonlító vizsgálata telemetriás adatok alapján.] Orv Hetil. 2017; 158: 748-753. [Hungarian]

[23] Walsh JT, Charlesworth A, Andrews R, et al. Relation of daily activity levels in patients with chronic heart failure to long-term prognosis. Am J Cardiol. 1997; 79: 1364-1369.

[24] Manson JE, Greenland P, LaCroix, AZ, et al. Walking compared with vigorous exercise for the prevention of cardiovascular events in women. N Engl J Med. 2002; 347: 716-725.

[25] Orsini N, Mantzoros CS, Wolk A. Association of physical activity with cancer incidence, mortality, and survival: a populationbased study of men. Br J Cancer 2008; 98: 1864-1869.

[26] Freedson PS, Melanson E, Sirard J. Calibration of the Computer Science and Applications, Inc. accelerometer. Med Sci Sports Exerc. 1998; 30: 777-781.
(Melczer Csaba, Pécs, Vörösmarty M. u. 4., 7621 e-mail: csaba.melczer@etk.pte.hu)

\section{MEGHÍ Vó}

\section{A Szent János Kórház és Észak-budai Egyesített Kórházak Tudományos Bizottsága tisztelettel meghívja az érdeklődőket a következő tudományos ülésére.}

Időpont: 2017. szeptember 21. (csütörtök) 14 óra

Helyszín: Szent János Kórház Auditóriuma - 1125 Budapest, Diós árok 1-3.

Téma: Aktuális kérdések a belgyógyászat és a sebészet területén

Üléselnök: Prof. Dr. Jánosi András

\section{Előadások}

Dr. Lengyel Zoltán: Diabeteses nephropathia jelentősége, gyakorisága, és kezelése

20 perc

Dr. Lukovich Péter: Innováció a sebészetben és az endoscopiában

Minden érdeklődőt szeretettel várunk. 